\title{
A Perspective on Salvadorean Refugees: Interview with Rubén Zamora
}

Rubén Zamora served as Minister of the Presidency in El Salvador under the first junta following the coup that toppled the government of General Carlos Humberto Romero on October 15, 1979. Zamora resigned from the junta early in January 1980. His brother, E1 Salvador's AttomeyGeneral Mario Zamora, was assassinated on February 25, 1980. His life threatened, Rubén Zamora eventually had to flee, and has lived in Nicaragua and Mexico ever since. He was instrumental in the creation on April 1, 1980 of the Democratic Revolutionary Front (FDR), a coalition of political and student groups, trade unions and mass organizations. At present he is the chief negotiator of the FDR and its guerrilla arm, the Farabundo Martí National Liberation Front (FMLN). Zamora visited Canada early in November and met with senior officials at the Department of External Affairs, Members of Parliament, NGOs, and the National Conference of Catholic Bishops. He delivered lectures at several Canadian universities and found time to give the following interview to Refuge.

Alex Zisman: In spite of the election of a civilian government led by José Napoleón Duarte, and the call to eradicate human rights violations and return the country to an "effective democracy", the exodus of Salvadorean refugees has not diminished considerably, and at certain times has even substantially increased. How can one account for this?

Rubén Zamora: I believe that the explanation of this phenomenon has a political character. In El Salvador we have a civilian President of the Republic, but the regime continues to be military in nature in so far as the govemment is one of counterinsurgency. What determines the actions of Duarte's government is precisely this counterinsurgency policy which generates bombardments and artillery attacks against the civilian population. This obviously continues to produce refugees who have to abandon their places of origin and move away to other places. Refugees continue to flock because fundamentally nothing has changed.

Alex Zisman: How do you view the situation of Salvadorean refugees within the present Central America context?

Rubén Zamora: I believe that a large percentage of Salvadorean refugees in Central America, Mexico and other countries wish to retum to El Salvador whenever that becomes

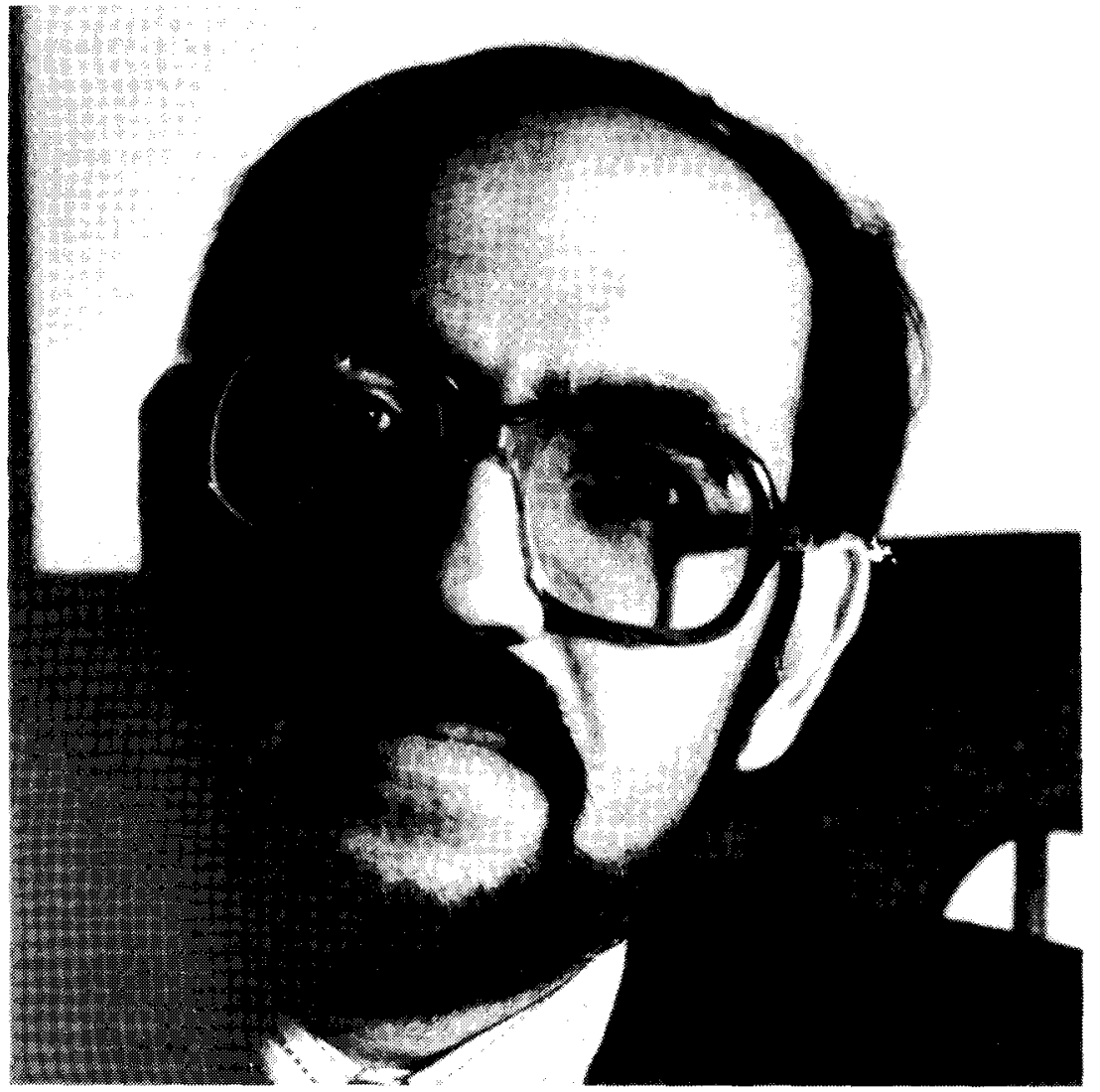

Rubén Zamora: "Being a refugee, in spite of all the sadness and the difficulties it entails, can also become an asset."

possible. This is an important phenomenon, because in some countries the refugees can acquire some knowledge, some types of training, which will be very useful once $\mathrm{El}$ Salvador becomes a truly just and democratic society. Nevertheless, we must clearly distinguish the case of countries such as Mexico, with a vast metropolis such as Mexico City, where Salvadorean refugees are dispersed among the city's 18 million inhabitants, from that of other countries such as Honduras, where the refugees have kept close to the Salvadorean border, and form communities which are strongly structured, where an attitude to return and a Salvadorean identity are firmly held. So much so that these communities have been able to fight and fend off the attempts by the United States and the Honduran governments to remove them from the border. It seems to me that the attitude of Salvadorean refugees in Nicaragua towards their country of origin is similar to that of their counterparts in Honduras. The future of the refugees lies in resolving the Salvadorean problem and, contrary to what the Reagan Administration is saying -- that a revolution in El Salvador would only create a flood of refugees -- I believe that if a just, democratic and peaceful regime could be achieved in El Salvador, many thousands of refugees would return immediately to the country to live and produce there as they did before.

Alex Zisman: Both in El Salvador and in Guatemala some unofficial factors prevail -- namely the effective control and presence of the military -- which prevent an immediate return to true democracy. Nevertheless we are led to believe that the conditions are ripe to encourage a return of refugees. What do you have to say about this?

Rubén Zamora: I believe that one of the tactics deployed by the Duarte government to legitimize itself before the international community has been precisely that, to try to tell everybody that they can return and that no problems exist. We have even detected in some cases attempts to forcefully induce refugees to return to the country. It seems to me that Duarte's claim does not correspond at all with reality. There are concrete cases of refugees who have returned to the country and even refugees in the United States who, because of United States immigration law, were deported back to El Salvador, have fallen in the hands of the security forces and disappeared. In this respect we believe that the conditions to ensure the return of refugees could only exist when the country really achieves peace and justice. Only 